Acta Theriologica 41 (4): 415-423, 1996.

PL ISSN 0001-7051

\title{
Digestive responses of wapiti Cervus elaphus canadensis to seasonal forages
}

\author{
Zhigang JIANG* and Robert J. HUDSON**
}

\begin{abstract}
Jiang Z. and Hudson R. J. 1996. Digestive responses of wapiti Cervus elaphus canadensis to seasonal forages. Acta Theriologica 41: 415-423.

We tested the hypothesis that seasonal differences in passage rate and digestibility of native forage in wapiti Cervus elaphus canadensis Erxleben, 1777 were due to seasonal appetence and digestive adaptation as well as plant phenology and composition. To this end, we compared digestive characteristics of seasonal pasture with those of a standard alfalfa-barley pellet fed to wapiti hinds throughout the year. No evidence of seasonal effects independent of forage quality was found. Although dry matter intakes differed 2-3 fold, the digestibility of the standard pelleted diet was not signficantly different in winter $(0.68 \pm 0.02)$, spring $(0.74 \pm 0.01)$ and summer $(0.71 \pm 0.01)$. However, digestibilities of natural forages increased greatly from winter $(0.51 \pm 0.01)$, to spring $(0.77 \pm 0.02)$, with a gentle decline into autumn $(0.65 \pm 0.02)$. Because retention times of pelleted diets were not significantly different among seasons (winter $28 \pm 1 \mathrm{~h}$, spring $24 \pm 2 \mathrm{~h}$, summer $22 \pm 1 \mathrm{~h}$ ), digestive kinetics also seemed to be mainly a function of seasonal composition of native forage rather than specific seasonal adaptation. The mean retention time of winter herbage $(41 \pm 2 \mathrm{~h})$ was significantly longer than that of spring $(28 \pm 3 \mathrm{~h})$ and summer $(25 \pm 2 \mathrm{~h})$ forages. Pasture forages were retained longer $(51 \pm 1 \mathrm{~h})$ than pellets in winter but not in spring $(28 \pm 1 \mathrm{~h})$ and summer $(27 \pm 1 \mathrm{~h})$. Fecal moisture was a good indicator of digesta retention time despite forage type and may provide a simple index of digestive function for field studies.
\end{abstract}

Department of Animal Science, University of Alberta, Edmonton, Canada T6G 2P5

Key words: Cervus elaphus, foraging ecology, digesta retention time, digestibility, digestion rate

\section{Introduction}

The unique multi-compartment digestive tract of Ruminantia and Tylopoda enables the animals to digest fibrous foods (Warner 1981, Lechner-Doll et al. 1990, Renecker and Hudson 1990). Long fiber particles are selectively retained and subjected to microbial fermentation in the reticulorumen. Although digestibility generally improves with longer retention time, gut fill as an outcome of longer

Present addresses:

*Department of Conservation Biology, Institute of Zoology, Chinese Academy of Science, Zhongguancun, Beijing 100080, China; Fax 010-255-5689, E-mail jiangzg@panda.ioz.ac.cn

**Renewable Resources, University of Alberta, Edmonton, Alberta, Canada T6G 2H1;

Fax 403-492-4323, E-mail robert.hudson@ualberta.ca. To whom correspondence should be sent. 
retention may limit food intake. Consequently, for any forage type, there is likely to be an associated optimal retention time, especially, for wild ruminants grazing native forages which have markedly different seasonal nutritive values (van Soest 1982, Baker and Hobbs 1987, Jiang 1993).

Species-specific adaptation to diets is associated with predictable morphophysiological characteristics of the gut (Kay 1987, 1989, Hofmann 1989) although body size also may be a factor in digestive kinetics (Gordon and Illius 1994, Robbins et al. 1995). Differences in digestion rates and ruminal microbial populations (Cederlund and Nystrom 1981) may contribute to the differences among browsers, mixed feeders and grazers, but the most important factor appears related to the kinetics of digesta passage (Renecker and Hudson 1990). Roughage feeders generally have longer retention times, larger gut fill and more complete digestion of forage than do concentrate selectors (Hofmann 1989).

Insights from inter-species dietary specialization may apply equally to seasonal adaptation within a species (Kay 1989). However, it is not clear whether seasonal digestive adaptation responds directly to diet or whether wild ruminants anticipate seasons using environmental cues such as photoperiod (Milne et al. 1978). To distinguish between these possibilities, we compared digestibility and passage rates of yearling wapiti Cervus elaphus canadensis Erxleben, 1777 hinds grazed on native pasture or fed standard alfalfa-barley pellets throughout the year.

\section{Methods}

\section{Study area}

The study was conducted at the Ministik Wildlife Research Station, Alberta, Canada $\left(53^{\circ} 18^{\prime} \mathrm{N}\right.$, $114^{\circ} 35^{`} \mathrm{~W}$ ) from September 1990 to August 1991 . The research station is located on dead ice moraine characterized by low hills covered with Populus forests interspersed with scattered lakes and ponds in depressions. Carex spp. dominated the wetlands whereas Bromus pumpelianus, Poa pratensis and Taraxacum officinale provided most of the herbage on grasslands. In the region, wapiti mainly fed on grasses and sedges (Gates and Hudson 1981, Jiang and Hudson 1993a, b, 1994a). In the year of the study, snow covered the ground from November to April.

\section{Experimental design}

The wapiti used in this experiment were managed following guidelines of the Canadian Council on Animal Care and the experimental protocols were approved by the Faculty Animal Care Committee. We determined apparent digestibility $(\mathrm{AD})$, mean retention time (MRT) and dry matter intake (DMI) of 12 yearling hinds in 1990-1991. Half of the wapiti were pastured throughout the year but were offered supplementary alfalfa and brome hay during late winter (December-March). The control group was offered ad libitum alfalfa and barley pellets, a standard ration allowing adequate nutrition (Table 1) without limiting gut capacity.

Cured winter herbage was harvested in the study area in October just before snow covered the pasture (here herbage to distinguish hand-fed material from forage which refers to grazed material). Herbage reflected the natural winter diet because snow and low temperature protect forage from weathering until early spring and was used in pen trials in November and April. The spring flush of vegetation, well under way during the late May grazing trials, caused marked increases in forage 
Table 1. Composition of pelleted diet and forages collected on specific dates from pasture.

\begin{tabular}{lcccccr}
\hline & $\begin{array}{c}\text { Energy } \\
(\mathrm{kJ} / \mathrm{g})\end{array}$ & $\begin{array}{c}\text { Protein } \\
(\%)\end{array}$ & $\begin{array}{c}\text { ADF } \\
(\%)\end{array}$ & $\begin{array}{c}\text { NDF } \\
(\%)\end{array}$ & $\begin{array}{c}\text { Lignin } \\
(\%)\end{array}$ & $\begin{array}{r}\text { Ash } \\
(\%)\end{array}$ \\
\hline Pellets (alfalfa/barley) & 17.5 & 17.1 & 14.2 & 29.3 & 3.4 & 6.4 \\
Winter herbage (10 November 1990) & 17.1 & 9.6 & 39.0 & 68.5 & 5.4 & 11.0 \\
Spring forage (20 May 1991) & 18.0 & 16.7 & 18.0 & 35.5 & 2.0 & 6.8 \\
Summer forage (23 July 1991) & 17.6 & 16.0 & 36.4 & 67.0 & 5.3 & 7.9 \\
\hline
\end{tabular}

quality as indicated by high protein and low cellulose (Table 1). More mature summer forages with $16 \%$ protein and $67 \%$ acis detergent fiber (ADF) were evaluated in grazing trials in late July.

Herbage intakes were recorded during pen trials and pasture forage intakes were estimated according to Jiang and Hudson (1992, 1994b). Intakes of the pellet-fed group were recorded weekly during group feeding and daily during individual feeding.

\section{Passage rate}

Chromic oxide $\left(\mathrm{Cr}_{2} \mathrm{O}_{3}\right)$ at a concentration $0.404 \%$ was used as an indigestible marker pelleted with ground alfalfa and barley (Jiang and Hudson 1992). The wapiti were placed in individual stalls and each was given $250 \mathrm{~g}$ labeled pellets (less than $10 \%$ and $3 \%$ of their daily DMI in winter and spring-summer, respectively). Normally, the wapiti consumed the pellets with 10 minutes without prior fasting. After consuming the marked pellets, the wapiti were released to group pens (pellet and herbage trials) or to pasture (free-ranging trials).

From 11 to 14 fresh voided fecal samples were collected opportunistically. For the first two days, fecal samples were collected at 4-6 h intervals, but less frequently in the following days. Fecal samples were collected opportunistically as wapiti grazed on pasture. Although fresh feces could be easily collected from snow in winter, feces on bare ground and pasture in spring and summer were sometimes contaminated with soil or litter; only the top layer of the feces was collected.

Samples were dried at $60^{\circ} \mathrm{C}$, ground through 20-mesh screen of a Wiley Mill, and sub-sampled for determining neutral detergent fiber (NDF), acid detergent fiber (ADF) and lignin. About $2 \mathrm{~g}$ ground sample was weighed before and after drying at $110^{\circ} \mathrm{C}$ overnight. The procedure for chromium determination was modified from Fenton and Fenton (1979). The sample was ashed at $550^{\circ} \mathrm{C}$ in a muffle furnace overnight. The ashed sample was digested in a ventilation hood at $250-300^{\circ} \mathrm{C}$ on a hot plate in a solution of $150 \mathrm{ml}$ distilled water, $150 \mathrm{ml}$ concentrated sulfuric acid, and $200 \mathrm{ml} 70 \%$ perchloric acid, until beakers that contained samples of high chromium turned into orange color. The digesta was then filtered through No. 4 Whatman filter paper and diluted to known volume. The absorbance of the filtrate was determined by atomic absorption spectrophotometry using an air-acetylene flame (Jiang and Hudson 1992).

Mean retention time (MRT) was calculated as follows:

$$
\operatorname{MRT}=\sum_{i=1}^{n} \frac{\mathrm{M}_{i}\left(\mathrm{t}_{i}-\mathrm{t}_{0}\right)}{\mathrm{MD}}
$$

where: $\mathrm{M}_{i}$ is the determined marker concentration in sample $i, \mathrm{t}_{i}$ is the sampling time of fecal sample $i$, to is the dosing time, MD is the marker dosage.

\section{Digestibility}

Digestibility of pellets and herbage in pen trials were determined by total fecal collection or from the ratio of indigestible internal markers in forage and feces. Digestibilities of pasture forages by free-ranging animals during the snow-free season were determined with ratio of chromogen and feces. 
Chromogen was extracted from ground dry samples in $85 \%$ acetone and determined by spectophometric absorption at $406 \mathrm{~m} \mu$ (Jiang 1993, Jiang and Hudson 1994b).

We estimated total digestive tract digestion rate $(\mathrm{DR}, \% / \mathrm{h})$ from forage indigestibility $(1-\mathrm{AD})$ and mean retention time (MRT).

$$
\mathrm{DR}=-\ln (1-\mathrm{AD}) / \mathrm{MRT}
$$

Indigestible residue has been taken into consideration, Equation (2) can be written as:

$$
\mathrm{DR}=-\ln (\mathrm{FI}+\mathrm{FD}-\mathrm{AD}) / \mathrm{MRT}
$$

where: $\mathrm{FI}$ is the fraction of indigestible portion and $\mathrm{FD}$ is the fraction of potentially digestible matter of the food.

\section{Statistics}

Analysis of variance of repeated measures design (Super ANOVA, Abacus Concepts 1989) was used to test seasonal and dietary differences of mean retention time and fitted parameters. The relationship between fecal dry matter rates and mean retention time, as well as dry matter intake and mean retention time were explored by regression analysis. Multiple-comparisons among means were carried out with the Tukey-Kramer test. Data were summarized as mean $\pm \mathrm{SE}$ and differences were considered significant where probability of Type I error did not exceed 0.05 .

\section{Results}

Free-ranging wapiti faced strong seasonal cycles of forage quality (Table 1). During the snow season, they fed unselectively from feeding craters in the snow field. In late May when pasture growth was lush, protein content in forage increased to $17 \%$ before gradually declining with maturation of summer forage. These seasonal diets were associated with changes in passage rates and digestibilities.

\section{Passage}

Mean retention time of wapiti on natural diets changed seasonally (Fig. 1). Winter herbage was retained for over $40 \mathrm{~h}$, significantly longer than spring and summer forages $(p<0.05)$. Spring-summer forages were retained less than $30 \mathrm{~h}$, about the same duration as pellets $(F=1.51, p=0.25)$. Pellets were retained

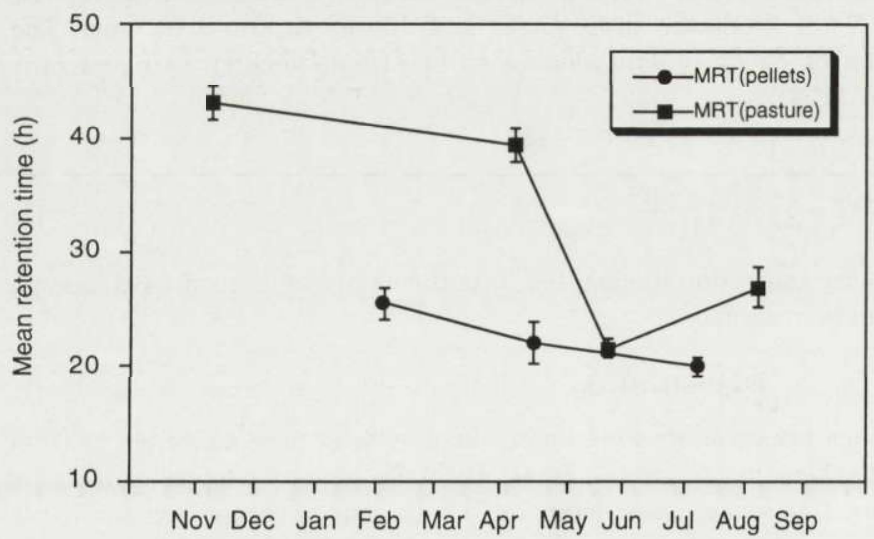

Fig. 1. Seasonal mean retention times of pasture forages and alfalfa/barley pellets by yearling wapiti. 
Fig. 2. Correlation between mean retention time (h) and fecal dry mater rate.

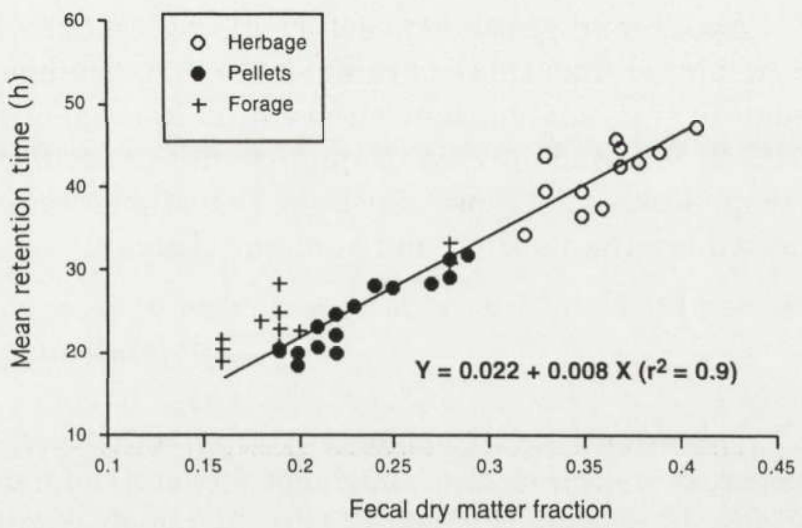

slightly longer in winter than summer, but the difference was not significant $(F=3.18, p=0.07)$.

For each food type (pellets and pasture), mean retention time was not related to daily dry matter intake. However, fecal dry matter rate was closely correlated with the mean digesta retention time $\left(r^{2}=0.90, p<0.01\right.$, Fig. 2$)$.

\section{Digestion}

Apparent digestibility coefficients were significantly affected by seasonal diets. In parallel with seasonal fiber and protein contents, digestibility of pasture forages increased from winter to spring, then declined through summer to autumn. Alfalfa-barley pellets provided wapiti with a high protein, low fiber diet which had a similar digestibility in all seasons (Table 2). Thus, digestive adaptation appeared related to diet quality rather than seasonal factors such as photoperiod or temperature.

Table 2. Digestive parameters (mean \pm standard error) of wapiti. BW - body weigt, DMI - dry matter intake, MRTr, MRTh - reticulo-rumen, hindgut retention times, TT - transit time. There were no differences $(p>0.05)$ among values which share superscript letter in the same column.

\begin{tabular}{llccccccc}
\hline Date & Diet & $\begin{array}{c}\text { BW } \\
(\mathrm{kg})\end{array}$ & $\begin{array}{c}\text { DM } \\
(\mathrm{g} / \mathrm{kg})\end{array}$ & $\begin{array}{c}\text { Apparent Digestion } \\
\text { digest- } \\
\text { ibility }\end{array}$ & $\begin{array}{c}\text { MRTr } \\
\text { rate }(\% / \mathrm{h})\end{array}$ & $\begin{array}{c}\text { MRTh } \\
(\mathrm{h})\end{array}$ & $\begin{array}{c}\text { TT } \\
(\mathrm{h})\end{array}$ \\
\hline 3 Feb 1991 & pellets & $131 \pm 9^{\mathrm{a}}$ & $17 \pm 2^{\mathrm{a}}$ & $68 \pm 2^{\mathrm{ad}}$ & $4 \pm 0.3^{\mathrm{b}}$ & $12.6 \pm 2.2^{\mathrm{ab}}$ & $7.8 \pm 1.4^{\mathrm{a}}$ & $8.8 \pm 0.8^{\mathrm{bc}}$ \\
18 Apr 1991 & pellets & $141 \pm 6^{\mathrm{a}}$ & $18 \pm 3^{\mathrm{a}}$ & $74 \pm 1^{\mathrm{ac}}$ & $6 \pm 0.6^{\mathrm{c}}$ & $8.4 \pm 1.4^{\mathrm{b}}$ & $5.0 \pm 1.7^{\mathrm{ac}}$ & $10.4 \pm 1.4^{\mathrm{b}}$ \\
8 Jul 1991 & pellets & $158 \pm 6^{\mathrm{b}}$ & $41 \pm 5^{\mathrm{c}}$ & $71 \pm 1^{\mathrm{a}}$ & $6 \pm 0.4^{\mathrm{c}}$ & $6.6 \pm 0.3^{\mathrm{b}}$ & $3.4 \pm 1.1^{\mathrm{ac}}$ & $20.9 \pm 1.0^{\mathrm{a}}$ \\
10 Nov 1990 & herbage & $129 \pm 7^{\mathrm{a}}$ & $20 \pm 2^{\mathrm{a}}$ & $51 \pm 1^{\mathrm{b}}$ & $2 \pm 0.1^{\mathrm{a}}$ & $16.4 \pm 2.6^{\mathrm{a}}$ & $7.2 \pm 1.6^{\mathrm{a}}$ & $20.9 \pm 1.0^{\mathrm{a}}$ \\
8 Apr 1990 & herbage & $129 \pm 7^{\mathrm{a}}$ & $22 \pm 2^{\mathrm{a}}$ & $51 \pm 2^{\mathrm{b}}$ & $2 \pm 0.1^{\mathrm{a}}$ & $16.4 \pm 1.5^{\mathrm{a}}$ & $3.8 \pm 1.6^{\mathrm{ac}}$ & $20.6 \pm 1.6^{\mathrm{a}}$ \\
24 May 1991 & pasture & $138 \pm 7^{\mathrm{a}}$ & $45 \pm 3^{\mathrm{b}}$ & $77 \pm 1^{\mathrm{c}}$ & $7 \pm 0.3^{\mathrm{c}}$ & $5.9 \pm 0.8^{\mathrm{b}}$ & $1.4 \pm 0.6^{\mathrm{bc}}$ & $11.8 \pm 0.5^{\mathrm{b}}$ \\
7 Aug 1991 & pasture & $163 \pm 7^{\mathrm{b}}$ & $29 \pm 3^{\mathrm{c}}$ & $65 \pm 1^{\mathrm{d}}$ & $4 \pm 0.3^{\mathrm{b}}$ & $9.6 \pm 1.3^{\mathrm{ab}}$ & $5.5 \pm 1.3^{\mathrm{ac}}$ & $7.3 \pm 0.3^{\mathrm{bc}}$ \\
\hline
\end{tabular}


Apparent digestibility coefficients reflect both digestion rate and retention time. Calculated from these parameters, total tract digestion rates of winter pellets were significantly higher than cured winter herbage. Digestion rates of seasonal pasture closely followed nutritional quality with particularly rapid digestion rates in spring when it exceeded those of pellets. Digestion rates of pellets were significantly lower in winter than spring and summer (Table 2).

\section{Discussion}

The wapiti is an opportunistic mixed-feeder, intermediate between the concentrate selectors and roughage feeder (Hofmann 1989, Renecker and Hudson 1990, Jiang and Hudson 1993b). Although wapiti respond to changing seasonal forage supplies by feeding selectively (Jiang and Hudson 1994a), they also respond to declining diet quality with prolonged retention of digesta. Because similar seasonal changes did not occur among wapiti fed a standard pelleted diet, the response seems directly related to forage quality. If wild ruminants anticipate seasons using environmental cues such as photoperiod, then both control and experimental groups should demonstrate a similar seasonal pattern.

\section{Methodology}

This study examined digestive dynamics of a wild ruminant on seasonal pastures and, therefore, adopted methods which required minimal intervention. The results are expected to be sensitive to methodology, particularly the choice of analytical models and indigestible markers. Unfortunately, season and method of determining digestibility were confounded in this study so conclusions about digestibility of seasonal natural diets are tentative. However, the important finding is that digestion of a standard pelleted diet did not vary seasonally despite wide differences in seasonal dry matter intake.

Holleman and White (1989) pointed out that digestive markers offer many advantages for studying wild ruminants. the main problem is selecting a suitable digestive marker (Warner 1981). Chromic sesquioxide, used in this study, may migrate separately from forage fibers (Uden et al. 1980). Chromium-mordanted fiber resolves this problem, but mordanting blocks microbial digestion sites (van Soest 1982). Longer mordanted fiber may not be broken down like forage particles (Spalinger and Robbins 1992). However, in wapiti, liquid and particulate phases tend to move together (Renecker and Hudson 1990, Spalinger et al. 1993) and this may be typical of mixed feeders and browsers (Kay 1993). At the same study site, MRT measured in wapiti offered chromium-mordanted fiber in 1992 showed no difference with the data in this study.

\section{Passage}

The rapid passage of pellets may be due to grinding of feed constituents (van Soest 1982). Lignified long fiber in winter herbage probably accounted for the slow 
movement of the digesta in the gut of wapiti. Wapiti fed pellets seldom ruminate whereas wapiti on herbage ruminate up to 14 hours per day (Jiang 1993).

Passage rates often are correlated with intake level in domestic ruminants (Warner 1981, van Soest et al. 1988). However, the relationship appears weak in deer and perhaps other mixed feeders and browsers (Domingue et al. 1991, 1992, Sibbald and Milne 1993). Reasons for strong seasonal cycles of appetite and cause-effect linkages to digestive function are not clear.

The correlation of fecal dry matter with retention time in wapiti confirmed findings in domestic ruminants (van Soest 1982). Measuring digesta retention in ruminants is time and labor intensive so this alternative indicator shows promise for field studies. Fecal samples can tell a great deal about digestion. Diet quality among seasons can be estimated from fecal protein (Gates and Hudson 1981, Hobbs 1987, Leslie and Starkey 1987), digestibility can be estimated from the ratio of inert markers in feces and forage (Jiang and Hudson 1994b), and digesta retention time may prove reliably related to fecal dry matter.

\section{Digestion}

Feed particles are subject to competing rates of digestion and passage. In the absence of fistulated animals, we attempted to calculate instantaneous digestion rates from passage rate and total tract digestibility. Based on the equation (2), we obtained values for winter forages which were of the same order of magnitude $(3.8 \% / \mathrm{h})$ as values determined for ruminally-fistulated wapiti fed timothy-brome hay (Renecker and Hudson 1990). Digestion rates generally are considered a function of diet quality rather than species-specific adaptation (Westra and Hudson 1981, Renecker and Hudson 1990).

\section{Digestive strategy}

Dry matter disappearance follows first order kinetics (Fig. 3). For slowly fermented foods, longer retention will enable wapiti to extract more nutrients, but for rapidly fermented foods, longer retention is not adaptive because most of the nutrients are digested in the early phase of digestion. When food is scarce and

Fig. 3. The food residual remaining as a function of digestion time based on the calculated digestion rates.

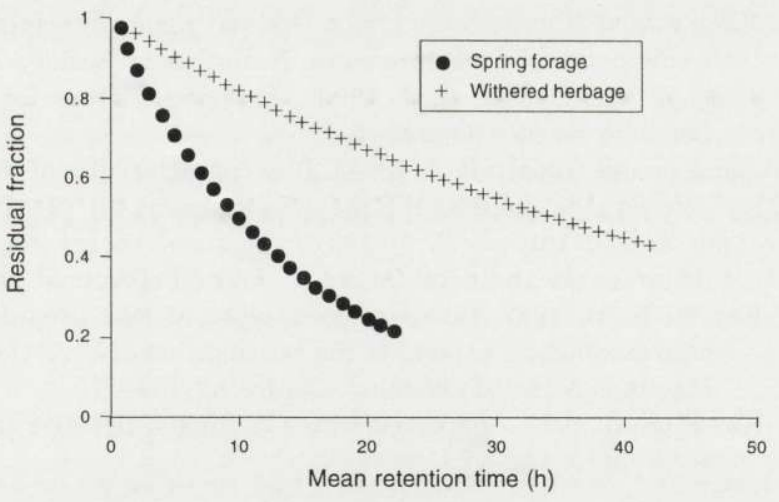


associated with high foraging costs, a digestive system which selectively retains foods is adaptive, even if the mechanism may constrain gut capacity.

Acknowledgment: We thank T. Fenton and Dr W. Sauer for advice. C. Olsen and S. Kallal for assistance in the field and P. Marceau for help in the laboratory. We also thank Dr I. Gordon, Macaulay Land Use Research Institute, for comments on the manuscript. We acknowledge financial support from the Natural Sciences and Engineering Research Council of Canada, the Alberta Agricultural Research Institute (Farming for the Future) and Canadian Circumpolar Institute.

\section{References}

Abacus Concepts. 1989. Super ANOVA. Abacus Concepts Inc., Berkeley, CA: 1-466.

Baker D. L. and Hobbs N. T. 1987. Strategies of digestion; digestive strategy and retention time of forage diets in montane ungulates. Canandian Journal of Zoology 65: 1978-1984.

Cederlund G. and Nystrom A. 1981. Seasonal differences between moose and roe deer in ability to digest browse. Holarctic Ecology 4: 59-65.

Domingue B. M., Dellow D. W., Wilson P. R. and Barry T. N. 1991. Comparative digestion in deer, goats, and sheep. New Zealand Journal of Agricultural Research 34: 45-53.

Domingue B. M., Dellow D. W., Wilson P. R. and Barry T. N. 1992. Effects of subcutaneous melatonin implants during long daylength on voluntary feed intake, rumen capacity and heart rate of red deer (Cervus elaphus) fed on a forage diet. British Journal of Nutrition 68: 77-88.

Fenton T. W. and Fenton M. 1979. An improved procedure for the determination of chromic oxide in feed and feces. Canadian Journal of Animal Science 59: 631-634.

Gates C. C. and Hudson R. J. 1981. Habitat selection by wapiti in a boreal forest enclosure. Naturaliste Canadien 108: 153-166.

Gordon I. J. and Illius A. W. 1994. The functional significance of the browser-grazer dichotomy in African ruminants. Oecologia 98: 167-175.

Hobbs N. T. 1987. Fecal indices to dietary quality: a critique. Journal of Wildlife Management 51: $317-320$.

Hofmann R. R. 1989. Evolutionary steps of ecophysiological adaptation and diversification of ruminants: a comparative view of their digestive system. Oecologia 78: 443-457.

Holleman D. F. and White R. G. 1989. Determination of digesta fill and passage rate from non absorbed particulate phase markers using the single dosing method. Canadian Journal of Zoology 67: $488-494$.

Jiang Z. 1993. Ecological and morphophysiological constraints on foraging by wapiti (Cervus elaphus). $\mathrm{Ph}$ D dissertation, University of Alberta, Edmonton, Canada: 1-114.

Jiang Z. and Hudson R. J. 1992. Estimating forage intake and energy requirement of free-ranging wapiti (Cervus elaphus). Canadian Journal of Zoology 70: 675-679.

Jiang Z. and Hudson R. J. 1993a. Optimal gazing of wapiti (Cervus elaphus) on grassland: patch and feeding station departure rules. Evolutionary Ecology 7: 488-498.

Jiang Z. and Hudson R. J. 1993b. Foraging postures of wapiti (Cervus elaphus). Applied Animal Behavior Science 36: 275-287.

Jiang Z. and Hudson R. J. 1994a. Bite characteristics of wapiti (Cervus elaphus) in seasonal Bromus-Poa swards. Journal of Range Management 47: 121-126.

Jiang Z. and Hudson R. J. 1994b. Seasonal energy requirements in wapiti (Cervus elaphus) for maintenance and gain. Canadian Journal of Animal Science 74: 97-102.

Kay R. N. B. 1987. Comparative studies of food propulsion in ruminants. [In: Physiological and pharmacological aspects of the reticulorumen. L. A. Ooms, A. D. Degryse and R. Marsboom, ed.s]. Martinus Nijhoff Publishers, Dordrecht: 159-173.

Kay R. N. B. 1989. Adaptation of the ruminant digestive tract to diet. Acta Veterinaria Scandanavica 86 (Suppl.): 196-203. 
Kay R. N. B. 1993. Digestion in ruminants at pasture. Proceedings to VII World Conference on Animal Production 7(1): 461-474

Lechner-Doll M., Rutagwenda T., Schwartz H. J., Schultka W. and Engelhardt W. V. 1990. Seasonal changes of ingesta mean retention time and forestomch fluid volume in indigenous camels, cattle, sheep and goats grazing a thornbush savannah pasture in Kenya. Journal of Agricultural Science 115: 409-420.

Leslie D. M. and Starkey E. E. 1987. Fecal indices to dietary quality: a reply. Journal of Wildlife Management 51: 321-325.

Milne J. A., MacRae J. C., Spence A. M. and Wilson S. 1978. A comparison of the voluntary intake and digestion of a range of forages at different times of the year by the sheep and the red deer. British Journal of Nutrition 40: 347-357.

Renecker L. A. and Hudson R. J. 1990. Digestive kinetics of moose (Alces alces), wapiti (Cervus elaphus) and cattle. Animal Production 50: 51-61.

Robbins C. T., Spalinger D. E. and van Hoven W. 1995. Adaptation of ruminants to browse and grass diets: Are anatomical-based browser-grazer interpretations valid? Oecologia 103: 208-213.

Sibbald A. M. and Milne J. A. 1993. Physical characteristics of the alimentary tract in relation to seasonal changes in voluntary food intake by the red deer (Cervus elaphus). Journal of Agricultural Science (Cambridge) 120: 99-102.

Soest P. J., van 1982. Nutritional ecology of the ruminant. O \& B, Corvallis, Oregon: 1-230.

Soest P. J., van, Sniffen C. J. and Allen M. S. 1988. Rumen dynamics. [In: Aspects of digestive physiology in ruminants. A. Dobson and M. J. Dobson, eds]. Comstock Publishing Associates, Ithaca: $21-42$.

Spalinger D. E., Robbins C. T. and Hanley T. A. 1993. Adaptive rumen function in elk (Cervus elaphus nelsoni) and mule deer (Odocoileus hemionus hemionus). Canadian Journal of Zoology 71: 601-610.

Uden P., Colluci P. E. and van Soest P. J. 1980. Investigation of chromium, cerium and cobalt as markers in digesta. Journal of Science of Food and Agriculture 31: 625-632.

Warner A. C. I. 1981. Rate of passage of digesta through the gut of mammals and birds. Nutrition Abstracts and Reviews 55: 789-820.

Westra R. and Hudson R. J. 1981. Digestive function of wapiti calves. Journal of Wildlife Management 45: 148-155.

Received 8 November 1995, accepted 23 April 1996. 